\title{
Citral as food additive for common snook - zootechnical parameters and digestive enzymes
}

\author{
Bruna Tomazetti Michelotti ${ }^{1}$ (D) Natacha Cossettin Mori ${ }^{2,3}$ (iD) Caio Cesar Franca Magnotti ${ }^{4}$ (D) \\ Berta Maria Heinzmann ${ }^{2,5}$ (D) Ana Paula Gottlieb Almeida ${ }^{6}$ (D) Vinicius Ronzani Cerqueira ${ }^{4}$ (D) \\ Bernardo Baldisserotto ${ }^{1,6^{*}}$ (D)
}

${ }^{1}$ Programa de Pós-graduação em Zootecnia, Universidade Federal de Santa Maria (UFSM), Santa Maria, RS, Brasil.

${ }^{2}$ Programa de Pós-graduação em Farmacologia, Universidade Federal de Santa Maria (UFSM), Santa Maria, RS, Brasil.

${ }^{3}$ Centro de Ciências da Saúde e Agrárias, Universidade de Cruz Alta (UNICRUZ), Cruz Alta, RS, Brasil.

${ }^{4}$ Laboratório de Piscicultura Marinha, Departamento de Aquicultura, Universidade Federal de Santa Catarina (UFSC), Florianópolis, SC, Brasil. ${ }_{5}^{5}$ Departamento de Farmácia Industrial, Universidade Federal de Santa Maria (UFSM), Santa Maria, RS, Brasil.

${ }^{6}$ Departamento de Fisiologia e Farmacologia, Universidade Federal de Santa Maria (UFSM), 97105-900, Santa Maria, RS, Brasil. E-mail: bbaldisserotto@hotmail.com. "Corresponding author.

ABSTRACT: Essential oils of plants whose main compound is citral showed beneficial effects when added to fish feed. The objective of the present study was to evaluate the dietary effect of the addition of citral on zootechnical parameters and digestive enzyme activities of Centropomus undecimalis. Juveniles were fed for 45 days with diets containing different amounts of citral (0.0 - control, 0.5, 1.0, and 2.0 $m L$ per $\mathrm{kg}$ of diet). The water quality parameters were kept stable during the experiment and no mortality was observed. At the end of the experimental period, the treatment $0.5 \mathrm{~mL}$ citral per $\mathrm{kg}$ of diet had the lowest weight gain and specific growth rate, and the highest feed conversion, while the same parameters did not differ between the other treatments. Pepsin activity was higher in the stomach of fish fed with $0.5 \mathrm{~mL}$ citral per $\mathrm{kg}$ of diet and amylase activity was higher in the intestine of fish fed with 0.5 and $2.0 \mathrm{~mL}$ citral per $\mathrm{kg}$ of diet compared to the control group. Intestinal lipase activity was higher in all groups that were fed with citral compared to the control group. Chymotrypsin and trypsin activities showed no difference between groups. Consequently, dietary addition of citral at any of the levels tested is not recommended for common snook.

Key words: Centropomus undecimalis, amylase, pepsin, lipase, growth, marine fish farming.

Citral como aditivo na ração para robalo flecha - parâmetros zootécnicos e enzimas digestivas

RESUMO: Óleos essenciais de plantas, cujo composto majoritário é o citral, mostraram efeitos benéficos quando adicionados à ração para peixes. O objetivo do presente estudo foi avaliar o efeito da adição de citral sobre os parâmetros zootécnicos e atividades das enzimas digestivas de Centropomus undecimalis. Os juvenis foram alimentados por 45 dias com dietas contendo diferentes quantidades de citral (0,0 - controle, 0,5, 1,0 e 2,0 $\mathrm{mL}$ por $\mathrm{kg}$ de ração). Os parâmetros de qualidade da água foram mantidos estáveis durante o experimento e nenhuma mortalidade foi observada. Ao final do periodo experimental, o tratamento $0,5 \mathrm{~mL}$ citral por $\mathrm{kg}$ de ração teve o menor ganho de peso e taxa de crescimento especifico e a maior conversão alimentar, enquanto os mesmos parâmetros não diferiram entre os demais tratamentos. A atividade da pepsina foi maior no estômago de peixes alimentados com 0,5 $\mathrm{mL}$ de citral por $\mathrm{kg}$ de ração e a atividade de amilase foi maior no intestino de peixes alimentados com 0,5 e 2,0 $\mathrm{mL}$ citral por $\mathrm{kg}$ de ração comparado ao grupo controle. A atividade da lipase intestinal foi maior em todos os grupos que foram alimentados com citral, em comparação ao grupo controle. As atividades de quimotripsina e tripsina não mostraram diferença entre os grupos. Consequentemente, a adição de citral na ração em qualquer um dos níveis testados não é recomendada para robalo flecha.

Palavras-chave: Centropomus undecimalis, amilase, pepsina, lipase, crescimento, piscicultura marinha.

\section{INTRODUCTION}

\section{Common snook, Centropomus} undecimalis, is a carnivore with several characteristics that qualifies it as a marine species for intensive fish farming, since it has high market value, is well adapted to captivity, easily accepts inert foods and has a good feed conversion ratio (RHODY et al., 2014; TUCKER JR, 1987). In addition, it is an important fish for sport fishing in 
the American continent (LOWERRE-BARBIERI; VOSE; WHITTINGTON, 2003).

The search for the maximum food efficiency has promoted the use of dietary additives to control harmful agents to the digestive process and thus improve the zootechnical indexes. Several essential oils (EOs) have been used as dietary additives for fish, improving growth and resistance to diseases ( ZHENG et al., 2009; FERREIRA et al., 2014; SÖNMEZ et al., 2015; MOHAMADI SAEI et al., 2016; BRUM et al., 2017; ZEPPENFELD et al., 2016, 2017).

Citral is the main compound of Aloysia triphylla EO (essential oil), whose dietary addition improved growth and oxidative status of silver catfish, Rhamdia quelen (ZEPPENFELD et al., 2016, 2017). Dietary supplementation with the microencapsulated EO of Cymbopogon flexuosus, which also has citral as the main compound, increased carcass yield and protein deposition in silver catfish (RAMPELOTTO et al., 2018). Often the major EO component is primarily responsible for its biological activities, but dietary supplementation with citral did not improve oxidative parameters and innate immunity in common snook (MORI et al., 2019). However, the effect of citral on growth and digestive enzymes activity in this species was not studied, then the objective of the present study was to evaluate the efficacy of dietary supplementation with citral as a growth promoter of common snook and to analyze its effects on digestive enzymes activities.

\section{MATERIALS AND METHODS}

\section{Animals and rearing conditions}

The experiments were performed in the Marine Fish Culture Laboratory (LAPMAR) at the Federal University of Santa Catarina (UFSC), Florianópolis, Santa Catarina, Brazil. Juvenile common snook Centropomus undecimalis (initial weight $2.75 \pm 0.02 \mathrm{~g}$ and total length $7.75 \pm 0.01 \mathrm{~cm}$ ) were obtained by induced spawning of brood stocks as described by PASSINI et al. (2013) and maintained at the LAPMAR in salinity $35 \mathrm{ppt}$.

Juveniles were randomly distributed in four water recirculation systems with salinity 31.12 $\pm 2.31 \mathrm{ppt}$ and temperature of $31.59 \pm 0.91{ }^{\circ} \mathrm{C}$ as suggested by MICHELOTTI et al. (2018) $(n=30$ per tank). Each recirculation system consisted of three circular tanks $(150 \mathrm{~L})$. The water contained in these experimental units was removed through a central pipeline with a bag filter $(50 \mu \mathrm{m})$, a biological filter, a foam fractionator and an ultraviolet sterilizer $(60 \mathrm{w})$. After the treatment, the water returned to the experimental tanks.

The fish were acclimated for four days to the experimental feed. Remains of food and feces were removed daily through siphoning, and an average of $25 \%$ of the water was renewed.

\section{Water parameters}

The water parameters were checked daily (temperature, $\mathrm{pH}$ and dissolved oxygen) or weekly (alkalinity, total hardness, ammonia and nitrite) throughout the experimental period, as described by MICHELOTTI et al. (2018). The water parameters remained stable during the experiment, with no significant difference between treatments (Table 1).

\section{Citral}

Citral $(\alpha$-citral $=60.15 \%, \beta$-citral $=39.85 \%)$ was obtained from Sigma-Aldrich ${ }^{\circledR}$ (St. Louis, Missouri, USA). The quantification of the isomers

Table 1 - Water quality (mean \pm standard error) of the four independent recirculation systems from a 45-day experiment with Centropomus undecimalis fed dietary citral supplementation.

\begin{tabular}{|c|c|c|c|c|}
\hline & Control & 0.5 & 1.0 & 2.0 \\
\hline Temperature $\left({ }^{\circ} \mathrm{C}\right)$ & $31.42 \pm 0.06$ & $31.49 \pm 0.06$ & $31.81 \pm 0.04$ & $31.62 \pm 0.04$ \\
\hline Dissolved oxygen $\left(\mathrm{mg} \mathrm{L}^{-1}\right)$ & $4.73 \pm 0.03$ & $4.51 \pm 0.07$ & $4.76 \pm 0.04$ & $4.54 \pm 0.02$ \\
\hline Dissolved oxygen (\%) & $75.75 \pm 0.05$ & $73.22 \pm 0.51$ & $75.58 \pm 0.64$ & $72.04 \pm 0.50$ \\
\hline $\mathrm{pH}$ & $8.17 \pm 0.01$ & $8.14 \pm 0.01$ & $8.19 \pm 0.01$ & $8.22 \pm 0.01$ \\
\hline Salinity (ppt) & $31.03 \pm 0.01$ & $31.21 \pm 0.05$ & $31.15 \pm 0.03$ & $31.03 \pm 0.01$ \\
\hline Alkalinity $\left(\mathrm{mg} \mathrm{CaCO}_{3} \mathrm{~L}^{-1}\right)$ & $102.16 \pm 12.41$ & $102.66 \pm 12.37$ & $102.33 \pm 5.87$ & $102.24 \pm 8.23$ \\
\hline Nitrite $\left(\mathrm{mg} \mathrm{L}^{-1}\right)$ & $0.27 \pm 0.08$ & $0.20 \pm 0.05$ & $0.29 \pm 0.03$ & $0.27 \pm 0.05$ \\
\hline Total ammonia $\left(\mathrm{mg} \mathrm{L}^{-1}\right)$ & $0.29 \pm 0.04$ & $0.26 \pm 0.03$ & $0.25 \pm 0.02$ & $0.32 \pm 0.07$ \\
\hline
\end{tabular}


was executed in an Agilent 6890A gas chromatography coupled with a 5973 mass selective detector using a HPCHIRAL capillary column ( $30 \mathrm{~m} \times 0.25 \mathrm{~mm}$ i.d. $\mathrm{x} 0.25$ $\mu \mathrm{m}$ film thickness) and electron ionization mode at 70 $\mathrm{eV}$. Helium was used as carrier gas in a flow rate of 1.0 $\mathrm{mL}$ min-1, injector temperature was set at $250^{\circ} \mathrm{C}$ and detector at $280{ }^{\circ} \mathrm{C}$. Oven temperature was kept at $40{ }^{\circ} \mathrm{C}$ for $4 \mathrm{~min}$ and raised to $240{ }^{\circ} \mathrm{C}$ at a rate of $4{ }^{\circ} \mathrm{C} \mathrm{min}$. Sample solutions of $1 \mu \mathrm{L}(2: 1000$ in hexane, v/v) were injected in a splitless mode. Kovats retention indices were calculated using a homologous series of C8-C40 n-alkanes injected under the same conditions of the samples. The isomers were identified by mass spectra and Kovats retention index comparison with data from the National Institute of Standards and Technology Mass Spectral Library (NIST). Compounds relative percent was estimated by under peak area integration obtained from the chromatogram.

\section{Diets and experimental design}

Four diets based on the same initial formulation (MORI et al., 2019) were produced, dried in an oven at $40{ }^{\circ} \mathrm{C}$; and subsequently, pelleted at $6 \mathrm{~mm}$ (Table 2). Different amounts of citral (0-control, 0.5, 1.0, $2.0 \mathrm{~mL}$ per $\mathrm{kg}$ of diet) were added to the mixture together with fish oil prior to the drying and pelletizing processes. Fish received the experimental diets to apparent satiety four times a day ( 9 a.m. and 1, 3 and 6 p.m.) for 45 days.
The feed was suspended $24 \mathrm{~h}$ prior to sampling and final collection of the experiment. The experimental design resulted in four groups (in triplicate).

\section{Samples}

After 45 days, three fish from each tank (n $=9$ animals per treatment) were anesthetized with 50 $\mathrm{mg} \mathrm{L}^{-1}$ of benzocaine and euthanized by sectioning of the spinal cord. Stomach and intestine were removed and immediately frozen in liquid nitrogen. The tissues were stored at $-20{ }^{\circ} \mathrm{C}$ for further analysis.

\section{Zootechnical parameters}

At 1, 22 and 45 days of experiment all Common sSnooks were anesthetized with $50 \mathrm{mg}$ $\mathrm{L}^{-1}$ benzocaine, measured and weighed to calculate weight gain $(\mathrm{Wg})$, specific growth rate (SGR) and feed conversion (FC) as described by MICHELOTTI et al. (2018). Condition factor (FK) was calculated by the following equation: $\left(\mathrm{FW} / \mathrm{FL}^{3}\right)^{*} 100$, where $\mathrm{FW}$ is the final weight and FL is the final length.

\section{Digestive enzymes}

Samples from stomach, anterior and posterior intestine were homogenized in an ice bath at ratio 1:10 (tissue: homogenization buffer) with an Ultraturrax. The homogenization buffer solution was composed by $20 \mathrm{mM}$ Tris/10 mM phosphate, $\mathrm{pH} 7.0$

Table 2 - Formulation (\%) of the experimental diet and analyzed proximate average composition.

\begin{tabular}{lcc}
\hline Ingredients & $\mathrm{g} \mathrm{kg}^{-1}$ \\
\hline Starch & 140 \\
\hline Soy lecithin & 10 & 5 \\
\hline Vitamins and minerals (premix) & \\
\hline Fresh squid & 120 \\
\hline Fish meal & 700 & 24 \\
Fish oil & 1 & $(\%)$ \\
\hline Vitamin C & 94.32 \\
Composition & 53.73 \\
\hline Dry matter content & 9.19 \\
Protein & 20.73 \\
\hline Ether extract & 2.04 \\
Mineral matter & 14.31 \\
\hline Acid detergent fiber & \\
\hline Neutral detergent fiber & \\
\hline
\end{tabular}

${ }^{*}$ Vitamin and mineral mixture (security levels per kilogram of product) — folic acid: $250 \mathrm{mg}$, pantothenic acid: $5,000 \mathrm{mg}$, antioxidant: $0.60 \mathrm{~g}$, biotin: $125 \mathrm{mg}$, cobalt: $25 \mathrm{mg}$, copper: $2000 \mathrm{mg}$, iron: $820 \mathrm{mg}$, iodine: $100 \mathrm{mg}$, manganese: $3750 \mathrm{mg}$, niacin: $5000 \mathrm{mg}$, selenium: $75 \mathrm{mg}$, vitamin A: 1,000,000 UI, vitamin B1: $1250 \mathrm{mg}$, vitamin B12: $3750 \mathrm{mcg}$, vitamin B2: $2500 \mathrm{mg}$, vitamin B6: $2485 \mathrm{mg}$, vitamin C: 28,000 mg, vitamin D3: 500,000 UI, vitamin E: 20,000 UI, vitamin K: $500 \mathrm{mg}$, zinc: 17,500 mg. 
in $50 \%(\mathrm{v} / \mathrm{v})$ glycerol. The extract was centrifuged and supernatant was utilized in assays as enzyme source.

Amylase activity was assayed in $0.2 \mathrm{M}$ phosphate-citrate buffer, $\mathrm{pH} 7.0,0.5 \% \mathrm{NaCl}$ with a starch concentration of $2.5 \%$. The reaction was stopped by adding $\mathrm{Ba}(\mathrm{OH})_{2} 0.3 \mathrm{~N}$ and $\mathrm{ZnSO}_{4} 5 \%$. The experimental protocol was modified according to BERNFELD \& COLOWICK (1955). The determination of starch hydrolysis was done following PARK \& JOHNSON (1949). The absorbance was recorded at $660 \mathrm{~nm}$. One unit of enzyme was defined as $1 \mathrm{mmol}$ of glycosyl-glucose released from starch per min per mg of protein.

Lipase activity was assayed as described by GAWLICKA et al. (2000) and Chymotrypsin and trypsin assay was performed according HUMMEL (1959). Pepsin activity was assayed as described by HIDALGO et al. (1999). Enzyme activities were calculated as described by ALMEIDA et al. (2018).

\section{Statistical analysis}

Results are expressed as mean \pm error. The Levene's test was performed to evaluate the homogeneity of variances of the data. Comparisons among treatments were made by one-way ANOVA followed by Tukey's test. All analyses were performed using Statistica Software 7.0 (Stat Soft, Tulsa, OK, USA), and differences were considered significant at $\mathrm{P}<0.05$.

\section{RESULTS}

\section{Zootechnical parameters}

Dietary addition of citral did not change significantly WG and FC compared to the control group at 22 days, but WG was lower and FC higher in fish fed with $0.5 \mathrm{~mL}$ citral per $\mathrm{kg}$ of feed than in those fed $1.0 \mathrm{~mL}$ citral per $\mathrm{kg}$ of feed. At the same day the lowest SGR and FK were observed in fish fed with $0.5 \mathrm{~mL}$ citral per $\mathrm{kg}$ of feed. After 45 days the lowest WG and SGR and the highest FC were observed in fish fed $0.5 \mathrm{~mL}$ citral per $\mathrm{kg}$ of feed (Table 3).

\section{Digestive enzymes}

The amylase activity was significantly higher in groups 0.5 and 2.0 citral per $\mathrm{kg}$ of feed than in the control group. Lipase activity was higher in all groups fed with citral compared to control group. Chymotrypsin and trypsin showed no significant difference between groups. However, pepsin was significantly higher in fish fed with 0.5 citral per $\mathrm{kg}$ of feed than control group (Figure 1).

\section{DISCUSSION}

The highest dietary insertion of citral did not affect significantly the Common Snook zootechnical parameters analyzed compared to control. In contrast, the lowest dietary insertion of citral $(0.5 \mathrm{~mL}$ citral per $\mathrm{kg}$ of feed) was harmful, with the worst values of WG, SGR and FC. A similar amount of dietary citral $(0.3 \mathrm{~g}$ citral per $\mathrm{kg}$ of feed) had no effect on the growth of Atlantic salmon (Salmo salar) after 30 days (JENSEN et al., 2015). Interestingly, dietary addition of the EO of ginger (Zingiber officinale) ( 5 or $10 \mathrm{~g}$ per $\mathrm{kg}$ of feed), which contains citral ( $\alpha$-citral 23.9\% and $\beta$-citral $17.2 \%$ ), did not affect final weight of Nile tilapia (Oreochromis niloticus) after 55 days, but 15 $\mathrm{g}$ per $\mathrm{kg}$ of feed of this EO decreased final weight

Table 3 - Zootechnical parameters (mean \pm standard error) of Common Snook, Centropomus undecimalis fed dietary citral supplementation

\begin{tabular}{|c|c|c|c|c|c|}
\hline & & Control & 0.5 & 1.0 & 2.0 \\
\hline \multirow{2}{*}{ WG (g) } & 22 & $3.86 \pm 0.24^{\mathrm{ab}}$ & $2.72 \pm 0.23^{b}$ & $4.64 \pm 0.24^{\mathrm{a}}$ & $4.08 \pm 0.26^{\mathrm{ab}}$ \\
\hline & 45 & $6.23 \pm 0.52^{\mathrm{a}}$ & $2.14 \pm 0.23^{\mathrm{b}}$ & $4.93 \pm 0.06^{\mathrm{a}}$ & $5.91 \pm 0.43^{\mathrm{a}}$ \\
\hline \multirow{2}{*}{ SGR $\left(\%\right.$ day $\left.^{-1}\right)$} & 22 & $3.97 \pm 0.16^{\mathrm{a}}$ & $3.11 \pm 0.19^{\mathrm{b}}$ & $4.48 \pm 0.14^{\mathrm{a}}$ & $4.12 \pm 0.17^{\mathrm{a}}$ \\
\hline & 45 & $2.87 \pm 0.13^{\mathrm{a}}$ & $1.42 \pm 0.07^{\mathrm{b}}$ & $2.22 \pm 0.05^{\mathrm{a}}$ & $2.71 \pm 0.22^{\mathrm{a}}$ \\
\hline \multirow{2}{*}{$\mathrm{FC}\left(\mathrm{g} \mathrm{g}^{-1}\right)$} & 22 & $1.83 \pm 0.08^{\mathrm{ab}}$ & $2.21 \pm 0.09^{b}$ & $1.46 \pm 0.07^{\mathrm{a}}$ & $1.76 \pm 0.05^{\mathrm{ab}}$ \\
\hline & 45 & $1.41 \pm 0.08^{\mathrm{a}}$ & $2.36 \pm 0.13^{\mathrm{b}}$ & $1.77 \pm 0.06^{\mathrm{a}}$ & $1.50 \pm 0.12^{\mathrm{a}}$ \\
\hline \multirow{2}{*}{$\mathrm{FK}\left(\mathrm{g} \mathrm{cm}^{-3}\right)$} & 22 & $0.86 \pm 0.005^{b}$ & $0.78 \pm 0.006^{\mathrm{a}}$ & $0.84 \pm 0.004^{b}$ & $0.85 \pm 0.02^{\mathrm{b}}$ \\
\hline & 45 & $0.83 \pm 0.003^{\mathrm{a}}$ & $0.78 \pm 0.006^{\mathrm{a}}$ & $0.80 \pm 0.018^{\mathrm{a}}$ & $0.80 \pm 0.008^{\mathrm{a}}$ \\
\hline
\end{tabular}

$\mathrm{WG}=$ weight gain $(\mathrm{g}), \mathrm{SGR}=$ specific growth rate, $\mathrm{FC}=$ feed conversion ratio, $\mathrm{FK}=$ condition factor. Different lowercase letters indicated significant difference between the treatments using one-way ANOVA and Tukey's test $(\mathrm{P}<0.05)$. 


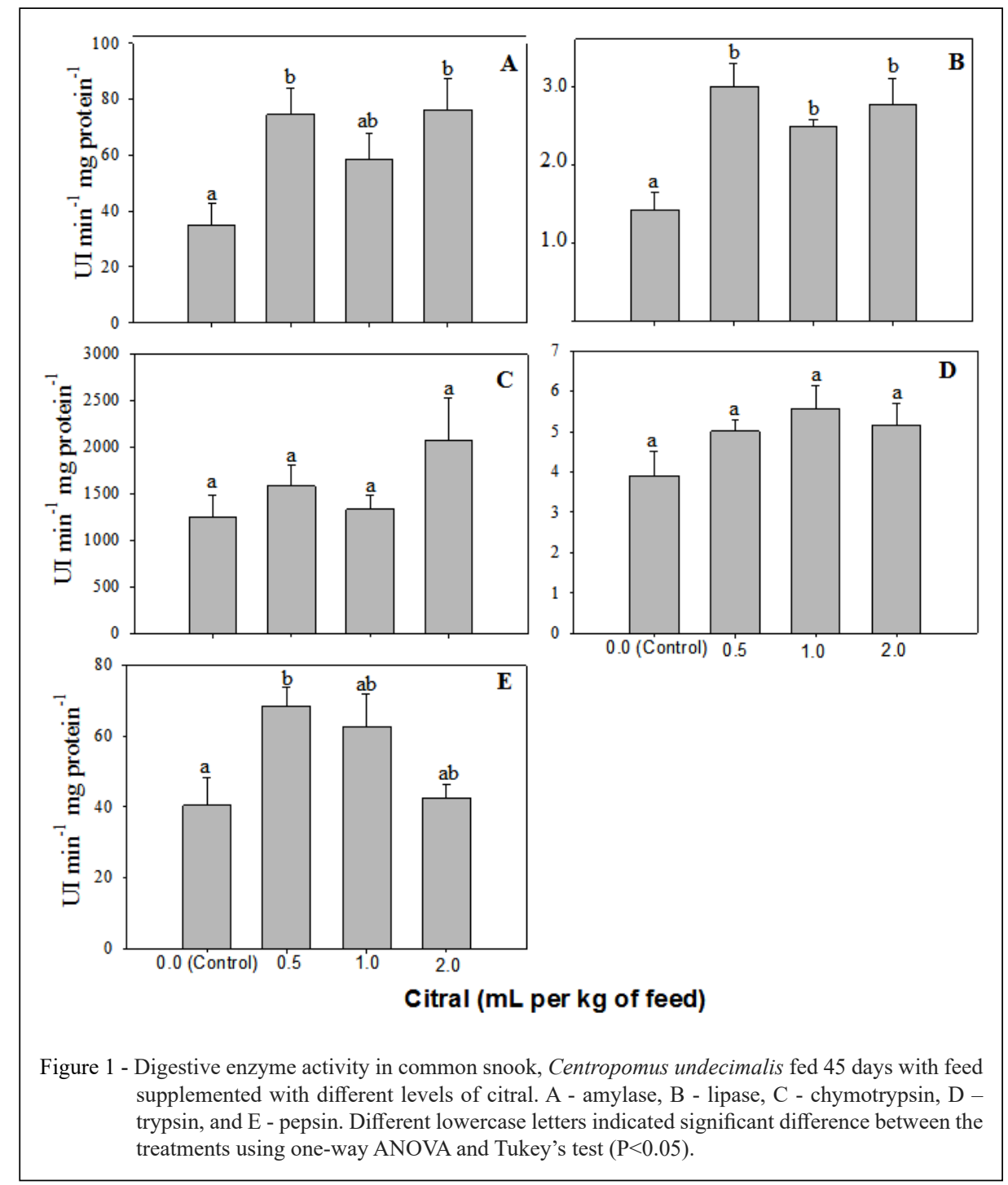

compared to control fish (BRUM et al., 2017). Silver catfish fed $2 \mathrm{~mL}$ EO of A. triphylla per $\mathrm{kg}$ of feed ( $\alpha$-citral $29.4 \%$ and $\beta$-citral $20.8 \%$ ) improved growth of silver catfish (ZEPPENFELD et al., 2016, 2017), but did not change growth of zebrafish (Danio rerio) (ZAGO et al., 2018). Dietary addition of 1 or $3 \mathrm{~mL}$ of microencapsulated EO of C. flexuosus (contains $\alpha$-citral $45.7 \%$ and $\beta$-citral $32.1 \%$ ), did not change growth parameters of silver catfish, but the duration of the experiment was only 30 days and the fish were adults. The group fed with $1 \mathrm{~mL}$ microencapsulated C. flexuosus EO per kg of feed increased carcass yield and protein deposition, but reduced the gonadosomatic index and fat deposition in comparison to the control group (RAMPELOTTO et al., 2018). Therefore, the effect of citral and EOs containing this compound as major constituent on fish growth varies according to the species and other compounds present in the EOs. A recent study demonstrated that the addition of citral to the diet of $C$. undecimalis juveniles at equivalent levels and for the same period is not beneficial, since oxidative damage was verified to the liver and gills of the animals (MORI et al., 2019).

There are no studies dealing with dietary addition of citral and digestive enzymes. The dietary addition of the microencapsulated EO of C. flexuosus did not change the activity of intestinal trypsin and chymotrypsin in silver catfish (RAMPELOTTO et al., 2018). The same authors suggested that the increased carcass yield and protein content verified in this species 
were not due to an improvement in protein digestibility. The only study that analyzed the effect of dietary EO supplementation and digestive enzymes activity in fish used the EO of cinnamon, which contains different main compounds (IMANI et al., 2017). The increase in the activity of the enzymes pepsin, amylase and lipase in Common Snook that received diets supplemented with citral may be due to an effort to improve the nutrient utilization efficiency. However, no clear relationship between the effect of citral on digestive enzymes activity and growth was observed.

\section{CONCLUSION}

Results obtained indicated that in spite of increasing the activity of some digestive enzymes, dietary addition of citral does not improve common snook growth, even impairing it at $0.5 \mathrm{~mL}$ citral per $\mathrm{kg}$ of feed. Therefore, dietary supplementation with citral is not recommended for Common Snook.

\section{ACKNOWLEDGEMENTS}

Authors would like to thank the National Council for Scientific and Technological Development (CNPq) for the support of master's and doctoral scholarships and for research grants. We would also like to thank the Coordination for the Improvement of Higher Education Personnel (CAPES), Brazil - financial code 001 for the financing.

\section{BIOETHICS AND BIOSSECURITY COMMITTEE APPROVAL}

The study was approved by the Ethics Committee on Animal Experimentation of Universidade Federal de Santa Catarina (UFSC) under registration $\mathrm{n}^{\circ} \mathrm{PP} 00861 / 2013$.

\section{DECLARATION OF CONFLICT OF INTERESTS}

The authors declare no conflict of interest. The founding sponsors had no role in the design of the study; in the collection, analyses, or interpretation of data; in the writing of the manuscript, and in the decision to publish the results.

\section{AUTHORS' CONTRIBUTIONS}

All authors contributed equally for the conception and writing of the manuscript. All authors critically revised the manuscript and approved of the final version.

\section{REFERENCES}

ALMEIDA, A. P. G. et al. Composition of gastrointestinal content, protease and lipase activities in summer and winter of four freshwater siluriforms (Teleostei: Actinopterygii) with two different feeding habits. Zoologia, v.35, p.1-8, 2018. Available from: $<$ https:// zoologia.pensoft.net/articles.php?id=13286>. Accessed: May, 10, 2018. doi: 10.3897/zoologia.35.e13286.

BERNFELD, P.; COLOWICK, S. P. Methods in enzymology. by SP Colowick and NO Kaplan. New York: Academic Press Inc, 1995.

BRUM, A. et al. Effect of dietary essential oils of clove basil and ginger on Nile tilapia (Oreochromis niloticus) following challenge with Streptococcus agalactiae. Aquaculture, v.468, n.1, p.235243, 2017. Available from: <https:/www.sciencedirect.com/ science/article/pii/S0044848616306925>. Accessed: May, 10, 2018. doi: 10.1016/j.aquaculture.2016.10.020.

GAWLICKA, A. et al. Activity of digestive enzymes in yolk-sac larvae of Atlantic halibut (Hippoglossus hippoglossus): indication of readiness for first feeding. Aquaculture, v.184, n.3-4, p.303314, 2000. Available from: <https://www.sciencedirect.com/ science/article/pii/S0044848699003221>. Accessed: May, 10, 2018. doi: 10.1016/S0044-8486(99)00322-1.

HIDALGO, M. C.; UREA, E.; SANZ, A. Comparative study of digestive enzymes in fish with different nutritional habits. Proteolytic and amylase activities. Aquaculture, v.170, n.3-4, p.267-283, 1999. Available from: <https://www.sciencedirect. com/science/article/pii/S004484869800413X>. Accessed: May, 10, 2018. doi: 10.1016/S0044-8486(98)00413-X.

HUMMEL, B. C. W. A modified spectrophotometric determination of chymotrypsin, trypsin, and thrombin. Canadian Journal of Biochemistry and Physiology, v.37, n.12, p.1393-1399, 1959. Available from: <https://www.nrcresearchpress.com/ doi/pdfplus/10.1139/o59-157>. Accessed: May, 10, 2018. doi: 10.1139/o59-157.

IMANI, A. et al. The effect of bentonite and yeast cell wall along with cinnamon oil on aflatoxicosis in rainbow trout (Oncorhynchus mykiss): Digestive enzymes, growth indices, nutritional performance and proximate body composition. Aquaculture, v.476, n.7, p.160-167, 2017. Available from: <https://www. sciencedirect.com/science/article/pii/S004484861730265X >. Accessed: May, 10, 2018. doi: 10.1016/j.aquaculture.2017.04.023.

JENSEN, L. B. et al. Reducing sea lice (Lepeophtheirus salmonis) infestation of farmed Atlantic salmon (Salmo salar L.) through functional feeds. Aquaculture Nutrition, v.21, n.6, p.983-993, 2015. Available from: <https://onlinelibrary.wiley.com/doi/ abs/10.1111/anu.12222>. Accessed: May, 10, 2018. doi: 251 10.1111/anu.12222.

LOWERRE-BARBIERI, S. K.; VOSE, F. E.; WHITTINGTON, J. A. Catch-and-release fishing on a spawning aggregation of common snook: does it affect reproductive output? Transactions of the American Fisheries Society, v.132, n.5, p.940-952, 2003. Available from: <http://www.tandfonline.com/doi/abs/10.1577/ T02-001>. Accessed: May, 10, 2018. doi: 10.1577/T02-001.

MICHELOTTI, B. T. et al. Growth and metabolic parameters of common snook juveniles raised in freshwater with di ff erent water hardness. Aquaculture, v.482, p.31-35, 2018. Available from: <https://www.sciencedirect.com/science/ article/pii/S0044848617309936>. Accessed: Dec. 12, 2018. doi: 10.1016/j.aquaculture.2017.08.029.

MOHAMADI SAEI, M. et al. Effects of dietary savory and myrtle essential oils on growth, survival, nutritional indices, serum biochemistry, and hematology of farmed rainbow trout, 
Oncorhynchus mykiss, Fry. Journal of the World Aquaculture Society, v.47, n.6, p.779-785, 2016. Available from: <https:// onlinelibrary.wiley.com/doi/full/10.1111/jwas.12306>. Accessed: Dec. 12, 2018. doi: 10.1111/jwas.12306.

MORI, N. C. et al. Citral as a dietary additive for Centropomus undecimalis juveniles: Redox,immune innate profiles, liver enzymes and histopathology. Aquaculture, v.501, p.14-21, 2019. Available from: <https:/www.sciencedirect.com/science/article/ pii/S0044848618303466>. Accessed: Apr. 7, 2019. doi: 10.1016/j. aquaculture.2018.11.003.

PARK, J. T.; JOHNSON, M. J. A submicrodetemination of glucose. Journal of Biological Chemistry, v.181, p.149-151, 1949. Available from <https://www.cabdirect.org/cabdirect/ abstract/19491404323>. Accessed: May, 10, 2018.

PASSINI, G et al. Primeira experiência de maturação e desova do robalo-flecha, Centropomus undecimalis, em cativeiro no Brasil. XI Reunião Cientifica do Instituto de Pesca, p.143-145, 2013. Available from: <https://www.pesca.sp.gov.br/11recip2013/ resumos/11a_ReCIP R44 143-145.pdf>. Accessed: May, 10, 2018.

RAMPELOTTO, C. et al. Supplementation with microencapsulated lemongrass essential oil improves protein deposition and carcass yield in silver catfish (Rhamdia quelen). Acta Scientiarum-Animal Sciences, v.40, p.1-8, 2018. Available from: <http://www.scielo. $\mathrm{br} / \mathrm{scielo} . \mathrm{php}$ ? pid $=\mathrm{S} 1807-86722018000100102 \& \mathrm{script}=\mathrm{sci}$ arttext>. Accessed: May, 10, 2018. doi: 10.4025/actascianimsci. v40i1.36517.

RHODY, N. R. et al. Parental contribution and spawning performance in captive common snook Centropomus undecimalis broodstock. Aquaculture, v.432, p.144-153, 2014. Available from: <https://www.sciencedirect.com/science/
article/pii/S0044848614001987>. Accessed: May, 10, 2018. doi: 10.1016/j.aquaculture.2014.04.022.

SÖNMEZ, A. Y. et al. Growth performance and antioxidant enzyme activities in rainbow trout (Oncorhynchus mykiss) juveniles fed diets supplemented with sage, mint and thyme oils. Fish Physiology and Biochemistry, v.41, n.1, p.165-175, 2015. Available from: <https://link.springer.com/article/10.1007/ s10695-014-0014-9>. Accessed: May, 10, 2018. doi: 10.1007/ s10695-014-0014-9.

TUCKER JR, J. W. Snook and tarpon snook culture and preliminary evaluation for commercial farming. The Progressive Fish-Culturist, v.49, n.1, p.49-57, 1987. Available from: $<$ https:// www.tandfonline.com/doi/abs/10.1577/1548-8640(1987)49\%3C4 9\%3ASATSCA\%3E2.0.CO\%3B2>. Accessed: May, 10, 2018. doi: $10.1577 / 1548-8640(1987) 49<49:$ SATSCA $>2.0 . C O ; 2$.

ZAGO, D. C. et al. Aloysia triphylla in the zebrafish food: effects on physiology, behavior, and growth performance. Fish physiology and biochemistry, v.44, n.2, p.465-474, 2018. Available from: $<$ https://link.springer.com/article/10.1007/s10695-017-0446-0>. Accessed: Dec. 12, 2018. doi: 10.1007/s10695-017-0446-0.

ZEPPENFELD, C. C. et al. Aloysia triphylla essential oil as food additive for Rhamdia quelen - Stress and antioxidant parameters. Aquaculture Nutrition, v.23, n.6, p.1362-1367, 2017. Available from: <https://onlinelibrary.wiley.com/doi/full/10.1111/anu.12511>. Accessed: May, 10, 2018. doi: 10.1111/anu.12511.

ZEPPENFELD, C. C. et al. Essential oil of Aloysia triphylla as feed additive promotes growth of silver catfish (Rhamdia quelen). Aquaculture Nutrition, v.22, n.4, p.933-940, 2016 Available from: <https://onlinelibrary.wiley.com/doi/full/10.1111/ anu.12311>. Accessed: May, 10, 2018. doi: 10.1111/anu.12311. 